\title{
HUMAN RIGHTS OF THE FOURTH GENERATION IN A SINGLE EDUCATIONAL AREA
}

\author{
Hanna L. Kokhan ${ }^{1}$ \\ Maksym I. Leonenko ${ }^{2}$ \\ Serhii M. Perepolkin ${ }^{3}$ \\ Tetiana L. Syroid ${ }^{4}$ \\ Iya V. Stryzhak ${ }^{5}$
}

\begin{abstract}
The relevance of the issue under study is determined by human rights appearance at the end of the $\mathrm{XX}$ the beginning of the XXI centuries that cannot be attributed to any of the three generations of human rights known to scholars; the doctrinal grounds of the necessity to unite them within the fourth generation of human rights; the lack of a universally recognized understanding of human rights of the fourth generation, and the ambiguous practice of their recognition and implementation on both the domestic and international levels. The purpose of the article is to develop the authors' model of understanding the concept and classification of human rights of the fourth generation and to make suggestions aimed at getting more
\end{abstract}

acquainted with them representatives of different peoples, to recognize them as quickly as possible and to ensure the most effective application in real life. The key method applied in the fourth generation of human rights research is generalization of the existing concepts of their interpretation within national law of different states, within international law, in the European Court of Human Rights practice, and in the doctrinal views of scientists. This title can be extended to rights not belonging to the first, the second and the third generations of human rights that have arisen at the end of the XX the beginning of the XXI centuries, as well as to human rights that will be revealed and interpreted in the future. As the fourth generation of

University of Customs and Finance, Volodymyr Vernadsky Street, 2/4, Dnipro, 490004, Ukraine, E- ${ }^{1}$ mail: kokhan-hanna9@tanu.pro

Zaporizhzhia Polytechnic National University, Zhukovsky Street, 64, Zaporizhzhia, 69063, Ukraine ${ }^{2}$ University of Customs and Finance, Volodymyr Vernadsky Street, 2/4, Dnipro, 490004, Ukraine ${ }^{3}$ V.N. Karazin Kharkiv National University, Svobody Square, 4, Kharkiv, 61022, Ukraine ${ }^{4}$ University of Customs and Finance, Volodymyr Vernadsky Street, 2/4, Dnipro, 490004, Ukraine ${ }^{5}$ 
human rights is in the process of its settling, the approaches to the classification of human rights based on exhaustive lists cannot fully reflect its real state. The content of this article may be of use to scholars studying human rights of the fourth generation, to lecturers teaching subjects dedicated to human rights, to students studying human rights, and to representatives of states and international organizations. involved in the development, recognition and practical implementation of human rights issues.

Keywords: digital rights, somatic (biological) rights, European Court of Human Rights

\section{Introduction}

Rights as a social and cultural phenomenon, accompany a person since her impregnation to her death. Their inexhaustible, inalienable and inviolable nature is recognized in universal, regional and bilateral international treaties, international customs and acts of international organizations. Art. 1 of the Charter of the United Nations, in particular, states on the implementation of international cooperation in order to promote and develop respect for human rights and fundamental freedoms for all people regardless of their race, gender, language and religion (De Frouville, 2005).

The stress on the importance of the support and further implementation of human rights and fundamental freedoms, as one of the methods of achieving closer unity between the members of the Council of Europe, is laid in the Preamble to the Convention for the Protection of Human Rights and Fundamental Freedoms. (European Convention..., 1950) The inviolability and inalienability of a human being rights; adherence to the principles of liberty, democracy, respect for human rights and fundamental freedoms, and the principle of a law-based state are recognized as the universal values in the Preamble of the Treaty on European Union (Consolidated versions..., 2012). At the same time, notwithstanding the mutual understanding as to manifestation of respect towards human rights and fundamental freedoms, the promotion and development of the effective exercise of civil, political, economic, social, cultural and other rights and freedoms deriving from human dignity inherent in human person and being 
crucial for her free and of full value development, unambiguous understanding of such rights and freedoms and their universally recognized list, and therefore the monotonous practice of international and national implementation, to date has not been produced.

The urgency of resolving of the abovementioned tasks as quickly as possible was confirmed by the emergence of new, derivative from the scientific and technological progress types of human rights, and the doctrinal justification of the necessity of their unification within a new - the fourth generation of human rights at the end of the $\mathrm{XX}$ the beginning of the XXI century. However, the theoretical discussion of these problems as well as the legal framework and practical implementation of the so-called "fourth generation of human rights", take place mainly at the national level, which significantly slows down the development of their universal understanding.

With regard to international measures in this field, the activities of the United Nations and of numerous international conferences on the human rights protection in terms of scientific and technological progress, started in 1968, remain little effective (Proclamation of Teheran..., 1968; General Assembly..., 1968; De Frouville, 2018; De Frouville and Tavernier, 2009). The necessity to intensify the international consideration on the issue of development of a common international concept of human rights of the fourth generation and the transition to a harmonized implementation of its provisions at both the international and national levels by the representative of various states is emphasized taking into consideration the above mentioned situation.

In this connection, the purpose of the suggested study is to develop the authors' model for understanding the concept and classification of human rights of the fourth generation and to elaborate suggestions aimed to widen their knowledge by the representatives of various peoples, to recognize them as quickly as possible and to ensure the most effective application in real life.

\section{Materials and Methods}

Achieving the goal of the paper stipulated the necessity to use various methods of scientific cognition to study the scientific work on human rights of 
the fourth generation, among them there are: historical and legal method; comparative method; method of analysis; synthesis method; method of generalization. The study of the issue was conducted in three stages:

At the first stage, there was a theoretical analysis of methodological approaches regarding the understanding of human rights and their classification into several generations existing in the legal scientific literature. Within the framework of the analysis, the human rights of the first, second and third generations were emphasized based on the classification of human rights by $\mathrm{K}$. Vasak. Examples of such human rights are given, as well as basic international legal acts by means of which human rights of the first, second, and third generations have been codified and offered for general consideration and recognition. Particular attention is paid to the human rights of the fourth generation evolution description and their recognition and consolidation in acts of both international and domestic law and decisions of the European Court of Human Rights.

At the second stage, the authors' approach to the interpretation of human rights of the fourth generation and determination of their possible types is suggested based on the results of the generalization of doctrinal approaches to the concept and types of human rights of the fourth generation, the provisions of acts of international and domestic law in this field, as well as the decisions of the European Court of Human Rights. According to the developed approach, given the incompleteness of the formation of the fourth generation of human rights, it is proposed to refuse to classify its rights on the basis of exhaustive lists.

At the present stage of the development of scientific and technological progress of human rights of the fourth generation it is suggested to recognize the rights in the field of digital technologies and somatic rights by means of generally recognized forms of international law (international treaties, acts of international organizations and international conferences). In the future, the classification of human rights of the fourth generation can be expanded due to other human rights.

At the third stage, suggestions aimed at acquaintance with the rights of the fourth generation of representatives of different peoples, their quickest recognition and elimination of obstacles 
to practical application in real life conditions were developed. It is suggested to step up information, lawmaking and law enforcement activities on these issues at universal, regional, bilateral and unilateral (national) levels.

Experimental implementation of such activities is offered to be developed in relations between the Member States of the European Union, focusing on the European Education Area building up to 2025. If the experiment is successfully completed, in particular, the international normative and legal consolidation of the concept and classification of human rights of the fourth generation, its results will become available to educational spaces of all interested subjects of international and national law.

\section{Results and Discussion}

General Description of Generations of Human Rights

It is suggested to intensify international cooperation in the way of developing a unified approach to human rights interpretation and its quickest international legal and domestic recognition by the result of the generalization of doctrinal approaches to understanding the category of "human rights of the fourth generation" and familiarization with the normative acts of international and domestic law in this field as well as the European Court of Human Rights decisions.

The practice of holding bilateral meetings of representatives of different states and peoples developing and the convening of multilateral international conferences, as well as involvement of regional and universal international organizations into such activities is suggested with this aim. The results of the meetings held should be recorded in general international treaties, acts of international organizations (declarations, recommendations, resolutions, etc.) and final acts of international conferences.

In the future, based on the adoption of international legal acts, interested states and peoples will have the opportunity, in particular through educational activities, to contribute to a wider acquaintance with the developed concept of understanding of human rights of the fourth generation, to deepen the knowledge of recognition and practical realization of such rights by other states and peoples, as well as to increase respect for these rights and to 
maximally provide them at both international and national level.

The experimental practical implementation of the abovementioned activities is proposed to develop in relations between the Member States of the European Union, focusing on forming the European Education Area to 2025 , within which it is planned to start making a single higher education area and a single European research area. However, investing in education is recognized as being of general interest to both the Member States of the European Union and to Europe in general. By virtue of this new jobs are created, economic growth is achieved, prosperity is improved, and development of economic and social convergence between and within Member States.

After all, investing in education is recognized as being of general interest to both the Member States of the European Union and to Europe as a whole. It creates new jobs, achieves economic growth, improves prosperity, and ensures the development of economic and social convergence between and within Member States. Along with culture, education helps to make Europe a more attractive place to live, study and work (Communication from..., 2017).

It should be noted that on the importance of paying special attention to the issues of guaranteeing and protecting human rights, as well as teaching them to future lawyers in the conditions of construction of the European educational area, other scientists from Ukraine have repeatedly emphasized, among whom it is appropriate to mention: L.M. Dobroboh, V.A. Zavgorodnii, O.O. Orlova (Dobroboh et al., 2019); R.S. Karahioz, O.V. Lehka, S.I. Minchenko (Karahioz et al., 2019); Yu.S. Zavhorodnia, A.M. Kuchuk and L.M. Serdiuk (Kuchuk et al., 2019).

Interpretation of the fourth generation of human rights, elaborated within the European educational area and confirmed by its participants, can later be used as a basis for developing a common definition of the "fourth generation of human rights" for all members of the international community; and after its international legal support can be used on the harmonized principles with the educational aim in the educational area of all concerned states and peoples.

It is suggested to use the name “Third Millennium Human Rights" as a 
61

possible generic name for the fourth generation of human rights. The suggested title can be extended to the rights non-belonging to the first, the second and the third generations of human rights originating at the end the $\mathrm{XX}$ the beginning of the XXI centuries, as well as human rights that will be revealed and interpreted in the future.

It is important to emphasize that such rights can be national (domestic) and international, individual and collective, positive and negative as well. The study of legal scientific literature in the field of human rights makes it clear that the classification of human rights by three generations, elaborated by $\mathrm{K}$. Vašák (1977) at the end of 1970s, is a common one for majority of scientists from different countries.

According to its provisions, the first generation of human rights belongs to negative rights and constitutes a complex of civil and political rights, namely: the right to life, the right to liberty, the right to respect for human dignity, etc. Their legal framework was summed up by the adoption of the International Covenant on Civil and Political Rights of December 16, 1966.

The second generation of human rights is a complex of economic, social and cultural rights, such as the right to work, the right to rest, the right to social protection, the right to housing, the right to education, the right to freedom of cultural, scientific and creative activities, which inherently are positive rights. Their legal support was also achieved through the adoption of a codified international act - the International Covenant on Economic, Social and Cultural Rights of December 16, 1966. (International Covenant..., 1966a; International Covenant..., 1966b). K. Vašák (1977) called the third generation of human rights "rights of solidarity" because their observance requires collective positive actions by individuals and legal entities, as well as by all subjects of international law in general.

The most famous examples of these are the right to self-determination, the right to a safe environment, the right to economic and social development, the right to peace, etc. It should be noted that, unlike civil, political, economic, social and cultural rights, the rights of solidarity, or, as they are called, collective rights, have not been enshrined in the content of one codified international legal act. Therefore, they can be mentioned in the Stockholm 
Declaration on Environmental Issues 1972, the Declaration on the Right to Development 1986, the Rio de Janeiro Declaration on the Environment and Development 1992 and other international declarative instrumentss (Declaration of the United..., 1972; Declaration on the Right..., 1986; Rio Declaration..., 1992).

At the same time, over the forty-one-year period since the conception of the division of human rights into three generations presented for the doctrinal debate by $K$. Vašák (1977), significant changes have taken place in the field of human rights. Some of them are associated with the advent of the turn on the $\mathrm{XX}-\mathrm{XXI}$ centuries of new types of human rights that cannot be attributed to any of the abovementioned human rights generations. Examples of such rights are the right to artificial insemination, the right to change sex, the right to die, the right to free access to the Internet, the right to use virtual reality and other rights. Development of scientific and technological progress, in particular, biology, genetics, medicine, chemistry, information technology is considered to be the prerequisite for their emergence.
62

In this regard, scholars from different countries have repeatedly made proposals to recognize lacking in the lists of the rights of the first, second and third generations of human rights human rights of the fourth generation. However, despite the fact that the scientific discussion as regards this has been going on for more than a decade, it is still not possible its participants to come to an agreement on a number of issues. One of the most controversial issues in this debate, in particular, is the specific differentiation of human rights of the fourth generation, approaches to understanding of which differ substantially from legal doctrine representatives.

\section{Doctrinal Approaches to}

\section{Understanding Human Rights of the}

\section{Fourth Generation}

A.V. Cornescu (2009), for example, refers rights related to genetic engineering, and assumes the ability to refer rights of future generations, rights that cannot belong to an individual nor to social groups, including nations, they belong only to humanity as a whole, and also rights deriving from exploration and exploitation of cosmic space to this generation of human rights. M.A. 
Lavrick (2005) states that the rights of the fourth generation embody the socalled somatic (from Greek soma body), or biological human rights, including the right to die, the human being right to dispose of organs and tissues of his/her body and to their transplantation, sexual human rights, reproductive rights of a human being (the right to artificial insemination, the right to abortion, the right to sterilization, the right to contraception), the right to change sex.

M.P Tirina (2011) and other scholars also suggest recognizing biological human rights as the rights of the fourth generation. In particular, F.M. Rudinsky (2000) believes that the fourth generation of human rights is linked to discoveries in the field of biology, including cloning, and is the barrier that protects a human being from experiments in genetic inheritance field. F. Pocar (2015) generally criticizing the concept of division of human rights into three generations to classify them, emphasizes that it has recently been suggested to add the fourth generation of human rights, including information technology rights to it.

V.A. Vitiv (2016) in this regard, concludes that the factors that allow the identification of information human rights exactly as of the fourth generation of rights is the new paradigm of freedom of information: the development and diffusion of information technology, the emergence of a global information space, the transition to new forms of social and economic order; changes in political processes (states with information society); the necessity to ensure the autonomy of actions and the choice of legitimate behavior of a person on the basis of equality of access to information, protection from incomplete, negative information and protection from the dissemination of personal information about the person, etc.

For his part, P.M. Sukhorolsky (2013) does not agree with the viewpoints of other scholars regarding the necessity to allocate all or only new information rights as the fourth generation of human rights. According to the scientist, information rights cover human rights that belong to all three generations, and a fundamental innovation that could lead to the emergence of a new generation of rights (digital rights, Internet rights) could be considered the separation of certain aspects of the information society into quite a new area to which the jurisdiction 
of states and the effects of the existing legal acts would not apply.

According to the authors of the study, the diversity of doctrinal approaches to understanding human rights of the fourth generation is an important testimony to the relevance of this topic for different peoples and states, as well as the conformation of the lack of a universally recognized international legal definition of human rights of the fourth generation. On the one hand, representatives of the international community of states are constantly working to eliminate this gap in international law by way of normative regulating of certain types of human rights of the fourth generation.

Thus, over the last few decades, the UN Declaration on the Human Genome and Human Rights, 1997, the International Declaration on Human Genetic Data 2003, the Universal Declaration on Bioethics and Human Rights 2005, the UN Declaration on Human Cloning 2005, have been adopted by the United Nations in this area of legal regulation. (Universal Declaration on the Human ..., 1997; International Declaration on Human Genetic, 2003; Universal Declaration on
64

Bioethics..., 2005; United Nations

Declaration..., 2005).

Convention for the Protection of Human Rights and Dignity of the Human Being with regard to the Application of Biology and Medicine (1997), and four additional protocols thereto, were developed with the direct involvement of the Council of Europe (Additional Protocol to the Convention for the Protection of Human Rights and Dignity of the Human Being with regard to the Application of Biology and Medicine, on the Prohibition of Cloning Human Beings (1998); Additional Protocol to the Convention on Human Rights and Biomedicine concerning Transplantation of Organs and Tissues of Human Origin (2002); Additional Protocol to the Convention on Human Rights and Biomedicine, concerning Biomedical Research (2005); Additional Protocol to the Convention on Human Rights and Biomedicine, concerning Genetic Testing for Health Purposes (2008)).

In addition, its Parliamentary Assembly and the Council of Ministers adopted more than fifty recommendations on stem cells, protection of the human genome, biotechnology and intellectual property, 
65

protection of medical data, trafficking in human organs, xenotransplantation, establishment of umbilical cord banks. (Texts of the Council..., 2014).

Provided that declarative rules of conduct predominance in this area of legal relations over legally binding obligations, judges of the European Court of Human Rights make an invaluable contribution to the development of a common concept of understanding human rights of the fourth generation. Their expertise is comprised of dozens of cases related to the various types of human rights that scholars refer to the fourth generation of human rights. Among the most famous of these are the following: B. v. France (European Court..., 1992); Laskey, Jaggard et Brown v. United Kingdom (European Court..., 1997); Diane Pretty v. United Kingdom (European Court..., 2002); Evans v. United Kingdom (European Court..., 2006); Vallianatos and Others v. Greece (European Court..., 2013).

On the other hand, the development of a uniquely international legal understanding of human rights of the fourth generation is significantly hindered by their unequal domestic legal and factual perceptions. In particular, homosexual relationships are commonplace in a number of states in Western and Northern Europe, Canada, the United States, and Australia. However, in Iran, Yemen, Saudi Arabia, Sudan, Nigeria, Somalia, Iraq and Syria, death is the punishment for the participating in such ties.

The right to euthanasia is recognized at the legislative level in Belgium, Luxembourg, the Netherlands and several US states, but euthanasia is prohibited in England, Bosnia and Herzegovina, Iran, France, the Russian Federation and other states, including Ukraine. In most countries of the world, the right of free access to the Internet is guaranteed for all persons without any restrictions. However, in the following states such as Belarus, India, Egypt, China, Myanmar (Burma), North Korea, Saudi Arabia, Syria and Turkey, access to the exercise of this right is strictly state-controlled and, in some cases, prohibited by criminal penalties.

Therefore, the results of a stepby-step analysis of the scientific and educational literature, international legal and domestic human rights instruments, as well as the practice of the European Court of Human Rights, suggest that the legal doctrine does not provide a unified approach to understanding the fourth 
generation of human rights. The practice of a narrow interpretation of the fourth generation of human rights is common among scholars from different states, according to which specific particular types of human rights are constituted, such as the human right to protection against stress, the right to die, sexual rights, the right to change sex or the right to the Internet access etc.

Attempts to uphold a broader interpretation of the fourth generation human rights are also common. However, despite recognizing several different types of human rights as fourth generation human rights, such as the right to peace, environmental rights, somatic rights, nuclear safety and space rights, their authors also consider the fourth generation human rights as an exhaustive list and not suggest the possibility of further evolution of their types differentiation.

According to the authors of the research, approaches to understanding the fourth generation of human rights, based on comprehensive human rights lists, should be considered debatable, as the latter is in its infancy and has not yet acquired its final form. Therefore, as long as the international community has come up with a unified approach to understanding the fourth generation of human rights and normatively defines it in a convenient international legal form, it is suggested to characterize the list of fourth generation human rights as inexhaustible, that is, open to enlargement.

\section{Conclusion}

It is established that developing a common approach for all peoples and states to understanding of human rights of the fourth generation will facilitate their more effective recognition and implementation at both international and national levels. The success of this goal depends on a number of factors, in particular, on the coordinated work of representatives of the legal doctrine of different states, as well as on the productive rulemaking and enforcement activities of states, international organizations and other entities of international law.

As the fourth generation of human rights, the substantive composition of which form the human rights of the third millennium continues its forming, doctrinal approaches to the classification of its rights based on exhaustive lists are unable to fully reflect neither its present nor its future status. 
Therefore, at the present stage of the development of scientific and technological progress towards the specific differentiation of human rights of the third millennium, it is suggested to include digital rights and somatic rights to them.

In the future, the classification of human rights of the fourth generation can be expanded due to other human rights. The materials in this article may be useful for the fourth generation human rights researchers, for lecturers giving lectures and subjects on human rights, for human rights students, and for officials of states and experts from international organizations that are responsible for the development, recognition and practical implementation of human rights.

Further scientific research and practical elaboration of these issues remains relevant both for individual states and for the entire international community. The unambiguous understanding of the human rights of the fourth generation is not developed not only at universal, but also at the regional and bilateral levels of international relations.

\section{References:}

Additional Protocol to the Convention for the Protection of Human Rights and Dignity of the Human Being with regard to the Application of Biology and Medicine, on the Prohibition of Cloning Human Beings. (1998). https://rm.coe.int/CoERMPublicCommo nSearchServices/DisplayDCTMContent ?documentId=090000168007f $2 \mathrm{ca}$

Additional Protocol to the Convention on Human Rights and Biomedicine concerning Transplantation of Organs and Tissues of Human Origin, (2002). https://rm.coe.int/CoERMPublicCommo nSearchServices/DisplayDCTMContent ?documentId=0900001680081562

Additional Protocol to the Convention on Human Rights and Biomedicine, concerning Biomedical Research. (2005).

https://rm.coe.int/CoERMPublicCommo nSearchServices/DisplayDCTMContent ?documentId=090000168008371a

Additional Protocol to the Convention on Human Rights and Biomedicine, concerning Genetic Testing for Health Purposes.

(2008). 
https://rm.coe.int/CoERMPublicCommo nSearchServices/DisplayDCTMContent ?documentId=0900001680084824

Communication from the Commission to the European Parliament, the Council, the European Economic and Social Committee and the Committee of the Regions "Strengthening European Identity through Education and Culture". (2017).

https://ec.europa.eu/commission/sites/be ta-political/files/communicationstrengthening-european-identityeducation-culture_en.pdf.

Consolidated versions of the Treaty on European Union and the Treaty on the Functioning of the European Union Consolidated version of the Treaty on European Union - Protocols Declarations annexed to the Final Act of the Intergovernmental Conference which adopted the Treaty of Lisbon, signed on 13 December 2007 - Tables of equivalences. (2012). https://eurlex.europa.eu/legal-

content/EN/TXT/?uri=celex\%3A12012 M\%2FTXT.

Convention for the Protection of Human Rights and Dignity of the Human Being
68

with regard to the Application of Biology and Medicine. (1997). https://rm.coe.int/168007cf98

Cornescu AV. (2009). The Generations of Human's Rights. Days of Law: the Conference Proceedings. Brno: Masaryk University.

De Frouville O. (2005). Article 1 Paragraphe 3'. In J-P Cot, A Pellet, M Forteau (Eds.), La Charte des Nations Unies: Commentaire Article par Article (pp. 357-378). Paris: Economica.

De Frouville O, Tavernier $\mathbf{J}$ (Eds.). (2009). La Déclaration universelle des droits de l'homme, 70 ans après: les fondements des drotis de l'homme au défi des nouvelles technologies. Paris: Publications du C.R.D.H.

De Frouville O. (2018). Le système de protection des droits de l'homme des Nations Unies. Présent et avenir. Paris: Publications du C.R.D.H.

Declaration of the United Nations Conference on the Human Environment (Stockholm Declaration). (1972). https://mwvlw.rlp.de/fileadmin/mwkel/ Abteilung_2/8206/06_Nachhaltigkeit_gl 
obal/1972_Stockholm_Erklaerung_en.p df

Declaration on the Right to Development. (1986).

https://undocs.org/en/A/RES/41/128

Dobroboh L, Zavhorodnii V, Orlova O. (2019). Legal education in Ukraine in the context of integration to the European educational space. The Asian International Journal of Life Sciences, 21(2), 421-432.

European Convention on Human Rights. (1950).

https://www.echr.coe.int/Documents/Co nvention_ENG.pdf.

European Court of Human Rights Application No. 13343/87 "Case of B. v. France". (1992). http://hudoc.echr.coe.int/rus?i=00157770.

European Court of Human Rights Application No. 21627/93; 21628/93; 21974/93 "Case of Laskey, Jaggard and Brown v. the United Kingdom”. (1997). http://www.cirp.org/library/legal/laskey 1997/.
European Court of Human Rights Application No. 2346/02 "Case of Diane Pretty v. the United Kingdom”. (2002). https://hudoc.echr.coe.int/rus\#\{\%22item id\%22:[\%22001-60448\%22]\}.

European Court of Human Rights Application No. 29381/09 and No. 32684/09 "Case of Vallianatos and Others v. Greece". (2013). http://hudoc.echr.coe.int/rus?i=00157770.

European Court of Human Rights Application No. 6339/05 "Case of Evans v. the United Kingdom”. (2006). https://hudoc.echr.coe.int/rus\#\%7B\%22 itemid $\% 22: \% 5 \mathrm{~B} \% 22001$ -

72684.\%22\%5D\%7D.

General Assembly Resolution 2450 (XXIII), Human Rights and Scientific and Technological Developments. (1986).

https://undocs.org/en/A/RES/2450(XXI

II)

International Covenant on Civil and Political Rights. (1966a). https://www.ohchr.org/en/professionalin terest/pages/ccpr.aspx 
International Covenant on Economic, Social and Cultural Rights. (1966b). https://www.ohchr.org/EN/ProfessionalI nterest/Pages/CESCR.aspx

International Declaration on Human Genetic. (2003).

http://portal.unesco.org/en/ev.php-

URL_ID $=17720 \& U R L \_D O=D O \_T O P I$

C\&URL_SECTION=201.html

Karahioz RS, Lehka O.V, Minchenko SI. (2019). Public administration of legal education in the practice of the European Court of Human Rights. The Asian International Journal of Life Sciences, 21(2), 493-504.

Kuchuk AM, Serdiuk LM, Zavhorodnia Y.S. (2019). Modern law education in the context of natural understanding of law. The Asian International Journal of Life Sciences, 21(2), 359-370.

Lavrick MA. (2005). On the Theory of Somatic Human Rights. Siberian Law Gazette, 3, 16-26.

Pocar F. (2015). Some Thoughts on the Universal Declaration of Human Rights and the "Generations" of Human Rights.
International Human Rights Review, 10, 43-53.

Proclamation of Teheran, Final Act of the International Conference on Human Rights.

(1968). http://legal.un.org/avl/pdf/ha/fatchr/Fina 1_Act_of_TehranConf.pdf

Rio Declaration on Environment and Development.

(1992). https://www.un.org/en/development/des a/population/migration/generalassembly /docs/globalcompact/A_CONF.151_26_ Vol.I_Declaration.pdf

Rudinsky FM. (2000. Civil Human Rights: General and Theoretical Issues. Law and Life, 31, 15-18.

Sukhorolsky PM. (2013). Problems of Ensuring and Development of Human Rights in Conditions of Information Society. Ukrainian Journal of International Law, 1, 18-23.

Texts of the Council of Europe on bioethical matters. (2014). https://www.coe.int/t/dg3/healthbioethic /Texts_and_documents/INF_2014_5_vo 1_II_textes_\%20CoE_\%20bio\%C3\%A9 thique_E\%20(2).pdf. 
Tirina MP. (2011). Human Rights and Municipal Law, 6, 22-26

Generations: Problems of Modern

Classification. State and Law, 52, 728732.

United Nations Declaration on Human

Cloning. (2005).

https://undocs.org/en/A/RES/59/280

Universal Declaration on Bioethics and Human Rights. (2005). http://portal.unesco.org/en/ev.phpURL_ID=31058\&URL_DO=DO_TOPI C\&URL_SECTION=201.html

Universal Declaration on the Human Genome and Human Rights. (1997). http://portal.unesco.org/en/ev.phpURL_ID=13177\&URL_DO=DO_TOPI C\&URL_SECTION=201.html

Vašák K. (1977). Human Rights: A Thirty-Year Struggle: the Sustained Efforts to give Force of law to the Universal Declaration of Human Rights. UNESCO Courier, 11, 29-32.

Vitiv V. (2016). Information Rights as a Component of Fourth Generation of Human Rights. Scientific Notes of Institute of Legislation of the Verkhovna 